\title{
ENTRE O DEVER DA TOGA E O APOIO À FARDA: Independência judicial e imparcialidade no STF durante o regime militar*
}

\author{
Alexandre Douglas Zaidan de Carvalho \\ Universidade de Brasília (UnB), Brasília - DF, Brasil. E-mail: dzaidan@hotmail.com
}

DOI: $10.17666 / 329415 / 2017$

\section{Introdução}

A transição entre regimes políticos democráticos e autoritários é permeada por uma assimetria conceitual no modo de definir a independência judicial. Incorporando-se ao catálogo de garantias sem as quais o Estado de Direito não pode ser reconhecido, a independência da magistratura e dos critérios de nomeação dos juízes jogam uma função-chave na forma como a política e o direito se refletem no discurso constitucional.

* Este artigo é uma versão revisada e ampliada de trecho da tese de doutorado Imagens da imparcialidade: entre o discurso constitucional e a prática judicial (Carvalho, 2016). Agradeço aos membros da banca, a Alexandre A. Costa, Raphael P. de Paula Marques e aos pareceristas anônimos da $R B C S$ por suas contribuiçóes. Quaisquer deficiências ainda existentes são de minha responsabilidade.

Artigo recebido em 28/06/2016

Aprovado em 17/02/2017
Essa antitética assimetria ${ }^{1}$ que cerca a relação entre os conceitos de Estado de Direito e de independência judicial pode ser observada em duas situaçóes distintas. Na transição da ditadura à democracia, a permanência de juízes indicados pelo regime autoritário parece ser tolerada e, embora não esteja isento de críticas, o argumento para tal permanência busca fundamento na ideia de independência e autonomia do Poder Judiciário, alinhando-se à noção de Estado de Direito. No entanto, o reflexo da instalação de um governo ditatorial sobre o sistema de justiça, caracterizado pela violaçáo às garantias de vitaliciedade e inamovibilidade, além da aposentadoria compulsória e o afastamento de membros da magistratura, constitui evidência de que, segundo os cânones do constitucionalismo liberal, já não se pode falar em Estado de Direito.

Enquanto conceitos fundamentais articulados na linguagem em disputa de uma comunidade política, os léxicos do Estado de Direito e da indepen- 
dência judicial sujeitam-se ao polêmico conflito semântico estabelecido entre grupos que reivindicam o monopólio sobre os seus significados. Entre as tensôes que se inserem nesse conflito estão a desconfiança na atuação política dos juízes ligados ao regime anterior e uma certa dependência do discurso de manutenção da autonomia do Poder Judiciário enquanto retórica de legitimação do novo regime. Esta última dimensão ganhou espaço durante o século XX, em especial na América Latina, quando o reconhecimento de governos que ascenderam ao poder sem eleiçóes precisou recorrer ao discurso da permanência e estabilidade das instituiçóes, vistas como condiçóes para que investidores nacionais e estrangeiros manifestassem apoio à mudança brusca no governo. Tal expectativa aumenta os custos políticos e reduz os estímulos a mudanças radicais na organização judicial, o que pode levar o novo regime a adotar distintas estratégias de remodelação do sistema de justiça segundo as diretrizes do governo (Garoupa e Maldonado, 2011, p. 598 e ss.).

Ainda que o baixo grau de politização das nomeaçóes, o uso do sistema judicial para perseguir a oposição política e a sua instrumentalização como aparelho de repressão sejam fatores reconhecidamente presentes em períodos autoritários, a explicação das razóes pelas quais regimes democráticos resolvem manter instituições judiciais herdadas em tais condiçóes encontra forte apoio na noçáo de independência judicial. Entretanto, a descrição da função do Supremo Tribunal Federal (STF) na instalação do regime autoritário, que vigorou entre 1964 a 1985, permanece ocupando um vácuo nos estudos sobre o papel dos juristas durante a ditadura (Seelaender, 2009). Mais do que nos países do antigo bloco socialista do Leste europeu ou de parte da América Latina (Sajó et al., 2003; Hilbink, 2008; Barros, 2008 e Bohoslavsky et al., 2015), persiste carente de explicação entre nós a pergunta de Díaz-Asensio ${ }^{2}$ sobre como a ditadura militar articulou a limitação judicial ao seu próprio poder ao tempo que conformou a organização do sistema de justiça segundo as diretrizes do regime.

Com o objetivo de compreender melhor como a interpenetração entre os discursos político e jurídico reformulou o sentido de independência judicial no STF durante a ditadura militar, que chegou ao governo pela via do golpe de Estado em 1964 e manteve-se no poder até 1985 , este trabalho buscou recuperar nos discursos de juristas e autoridades do governo os limites em que se inscreveu o espaço de autonomia da Corte. ${ }^{3}$

Ao procurar descrever as tensóes e os alinhamentos que alternaram momentos de auxílio e enfretamento ao regime, o texto segue cronologicamente os principais registros do discurso sobre a independência judicial, entre militares e juristas. A primeira parte destaca o apoio significativo de juristas e do STF ao golpe militar, o que envolveu a sua justificação. Observa-se em seguida a afirmação de certa autonomia do Tribunal representada por decisóes refratárias aos efeitos do primeiro Ato Institucional, contrariando as expectativas do governo. E logo, então, examina-se o contexto conflitivo que originou o AI-2 e o impacto da mudança de composição da Corte no desempenho independente de sua jurisdição.

Por sua vez, a segunda parte aproxima-se dos efeitos do AI-5 acerca da função da Suprema Corte, avaliando os discursos dos ministros afastados e a sua repercussão para a autocompreensão institucional do Tribunal. O realinhamento da organização interna do Judiciário com o perfil decisório é contextualizado a partir dos influxos da conjuntura política e o endurecimento do regime. Importa considerar aqui o reflexo da escalada autoritária na mudança do sentido da independência judicial na compreensão de alguns dos próprios ministros da Corte. O que indica o êxito do governo em remodelar o funcionamento do Tribunal de acordo com os propósitos que dirigiam a ação política do regime.

A análise articulada entre discursos e decisóes do Supremo no período mostra que a expressividade semântica da independência dos ministros variou de acordo com uma série de condicionantes políticas. Este diagnóstico parece se adequar à observação de que, quando em jogo a interpretação constitucional, o sentido da independência judicial no STF tem sido definido em torno da manutenção da ordem institucional e da garantia da governabilidade no regime presidencialista (Carvalho, 2016, p. 289). O que reduz significativamente as expectativas de imparcialidade na atuação dos ministros quando o Tribunal aprecia a eficácia de direitos cuja alta densidade política possa impactar na credibilidade do governo. 


\section{Do apoio à submissáo: o STF nos primeiros anos do regime militar}

A rejeição da inclusão de significativa parcela da população no sistema político, com o aumento da pressão por pautas de redução das desigualdades através de programas distributivos, pôs em xeque o discurso liberal que unia as elites políticas e econômicas no Brasil pós-Vargas. Entre outras contradiçóes, o golpe militar de 1o de abril de 1964 contou com o franco apoio de juristas que mais tarde reivindicariam o poder constituinte ao povo no processo de transição à democracia.

Afastando-se tanto das características dos regimes democráticos quanto das figuras presentes nos Estados totalitários, a coalizão entre civis e oficiais adotou o pluralismo limitado apoiado na redução da mobilização política como principal traço do governo, cujo desenho institucional se inseriu nos quadros de um regime autoritário burocrático-militar. ${ }^{4}$ Somada à promessa de manutenção do calendário eleitoral, do não rompimento com a Constituição de 1946 e da permanência do funcionamento do Congresso com uma oposição tolerada ou cooptada, além da propaganda do sucesso político-econômico do governo, incluiu-se entre os custos exigidos pela complexa fórmula de legitimação simbólica na fase inicial do regime a reserva de certa autonomia aos serviços judiciários e a outros setores profissionalizados da burocracia estatal.

Por suas características, a institucionalização do regime autoritário no Brasil demandou um grau maior de cooperação entre militares e civis, e, dentre estes, a especial contribuição daqueles que integravam a burocracia judicial. Como registra Anthony Pereira, o tipo de legalidade autoritária desenvolvida pelo regime militar brasileiro distinguia-se das demais ditaduras do Cone Sul pela "margem de manobra mais ampla, para que os réus e os grupos da sociedade que assumem a sua defesa consigam agir dentro dos limites do sistema". 5 Logo, o aparato de repressão estatal precisava articular a participação de juízes e advogados civis em procedimentos públicos que aparentemente garantissem a validade dos direitos dos opositores, aplicados por um sistema judicial visto como independente e imparcial. Essa foi uma das razóes do alto índice de judicialização da repressão na ditadura militar brasileira.

Embora o golpe tenha contado com amplo apoio e participação de segmentos populares e religiosos das diversas regiōes do país, no plano político, fazia sentido para os juristas evitar a identificação com o discurso moralista conservador ou com a mera referência de que o novo governo se fez necessário em face da ameaça comunista. Nas manifestaçóes públicas de aclamação da subida ao poder dos militares pelos juristas, a característica mais marcante foi a negação da expressão "golpe de Estado" para designar o movimento pelo nome através do qual ele se autodescrevia: "Revolução". ${ }^{6}$

Foi o caso de Goffredo Telles Junior, que publicou em 1965 o ensaio "A democracia e o Brasil: uma doutrina para a Revolução de março", 7 afirmando logo no início que a "Revolução Vitoriosa foi a sublevação do Brasil autêntico, em consonância com os mais profundos anseios da Naçáo". Telles Junior dedicou ainda um capítulo da obra à "resistência violenta aos governos injustos", justificando-o sob a guarda do direito natural à resistência. ${ }^{8} \mathrm{~A}$ versão de que o movimento de 1964 incorporou o sentido de revolução e não de golpe permaneceu na visão de juristas mesmo após anos do final do regime militar. É o caso, por exemplo, da descrição do ex-deputado udenista à época e ministro do STF entre 1982 e 1989, Oscar Dias Corrêa, que em 1994 afirmou ter ajudado a "fazer a Revolução, contra o caos que se instalara no Brasil” (Corrêa, 1994, p. 93), registrando seu rompimento com Castello Branco após a extinção dos partidos políticos em 1965, com a edição do Ato Institucional n. 2.

$\mathrm{Na}$ atividade decisória do Supremo logo após o golpe não se observou a defesa ou condenação explícita do regime que se instalava. A regra era o silêncio sobre os efeitos políticos da ascensão do governo militar. Entretanto, algumas exceçóes se fizeram presentes. Uma delas ocorreu em 24 de agosto de 1964, durante o julgamento do HC (habeas corpus) n. 40.910/PE - o primeiro com impacto político sobre o regime, impetrado pelo professor de economia Sérgio de Cidade Rezende. Ele era acusado de subversão por ter distribuído um manifesto contra a situação política a 26 alunos na Unicap, 
sugerindo que os militares gorilarizavam o país. Em sua decisão, o ministro Pedro Chaves manifestou apoio ao movimento militar, que denominou de "revolução". A unanimidade do Tribunal decidiu pela concessão da ordem, em razão da liberdade de cátedra e do reconhecimento de que a conduta do professor não constituía crime previsto na lei $\mathrm{n}$. 1.802/1953 (Lei de Segurança Nacional do segundo governo Vargas). Mas em seu voto, Chaves deixou clara a sua posição de alinhamento com os militares, ${ }^{9}$ colocando em xeque a própria permanência da validade da Constituição diante dos propósitos da "revolução", cujas diretrizes haviam alcançado expressão jurídica no primeiro ato institucional:

Há nesta revolução, no momento em que estamos vivendo, uma evidente contradição; alguma coisa está positivamente errada, porque se há ideias que se repelem que burlent de se trouver ensemble, são estas de revolução e de Constituição. E o Ato Institucional, que procurou dar colorido ao Movimento de 31 de março, no seu art. 1 o diz que está em vigor a Constituição de 1946.

Esta Constituição de setembro de 1946, como todas as Constituições inspiradas nos princípios da Liberal Democracia, é uma Constituição que não oferece meios de defesa às instituiçóes nacionais e é uma Constituição onde se prega um liberalismo à Benjamin Constant, pleno, amplo e absoluto, mesmo contra os interesses que se presumem ser da nacionalidade, porque consagrados por uma Assembleia Constituinte. ${ }^{10}$

Como observa Paixão, o uso político do léxico "Revolução" teve significado peculiar no discurso dos juristas empenhados em oferecer uma justificativa ao golpe (Paixão, 2014, p. 428). A ambígua manutenção da Constituição de 1946 com a adoção do discurso revolucionário do poder constituinte delimitava um campo semântico fundamental para a imagem do movimento. ${ }^{11}$ A promoção dessa imagem reduzia a dimensão contraditória de um governo autointitulado democrático que chegara ao poder pela deposição de um governo eleito. Todavia, sob o discurso de que o regime constitucional permanecia vigente, as diretrizes jurídicas dos militares assumiam a forma de atos institucionais que violavam frontalmente os mais diversos direitos fundamentais dos opositores do governo.

A trajetória de intervençóes na organização do Judiciário e do STF, em particular, oscilou bastante durante o regime militar. Dias após o golpe, em 17 de abril de 1964, Castello Branco foi recebido pelo presidente do STF, ministro Álvaro Ribeiro da Costa, que discursou em apoio ao regime justificando o sacrifício provisório de algumas garantias constitucionais (Viotti da Costa, 2006, p. 161). Ribeiro da Costa, que tinha fortes ligaçóes com udenistas, além de ser filho e irmão de militares, havia participado da sessão no Congresso Nacional na qual se declarou vaga a Presidência da República. $\mathrm{O}$ encontro entre Castello e Ribeiro da Costa foi confirmado pelo presidente do Senado, Auro Soares de Moura Andrade, que havia feito visita em agradecimento ao Supremo no dia anterior. ${ }^{12}$ Além disso, o presidente do Supremo também esteve presente no Palácio do Planalto para posse nominal de Ranieri Mazzilli, no dia 2 de abril, como registrou Aliomar Baleeiro em sua obra sobre o Supremo quatro anos mais tarde (Baleeiro, 1968, pp. 132-133). Contudo, naquele momento, as ameaças à independência do STF tinham mais ressonância na imprensa e no discurso isolado do deputado udenista paranaense Jorge Curi, na Câmara, do que nas atitudes do novo governo. Em abril de 1964, o Supremo Tribunal Federal tinha a composição expressa no Quadro 1.

Embora nenhuma prerrogativa do Tribunal tenha sido extinta, nem qualquer dos seus integrantes tenha sido afastado nos meses que se seguiram ao golpe, evidenciando a busca por uma possível aliança com a cúpula do Poder Judiciário, o mesmo não se repetia nos órgãos de base do sistema de justiça. $\mathrm{O}$ conjunto de restrições à independência judicial teve início com o primeiro Ato Institucional, de 9 de abril de 1964 , que, em seu artigo $7^{\circ}$, suspendeu por seis meses as garantias constitucionais de vitaliciedade e estabilidade, além de autorizar, no parágrafo $1^{\circ}$, a aposentadoria ou demissão via decreto presidencial de quaisquer servidores públicos, inclusive os magistrados.

$\mathrm{Na}$ magistratura, foram atingidos pelo primeiro ato institucional o ministro do Tribunal Federal de 
Quadro 1

Composição de Ministros do STF (01/04/1964)

\begin{tabular}{llll}
\hline & Nome & Posse & Nomeado por \\
\hline 1 & Álvaro Moutinho Ribeiro da Costa & $26 / 01 / 1946$ & José Linhares \\
\hline 2 & Antônio Carlos Lafayette de Andrada & $01 / 11 / 1945$ & José Linhares \\
\hline 3 & Hahnemann Guimarães & $24 / / 10 / 1946$ & Enrico Gaspar Dutra \\
\hline 4 & Luiz Gallotti & $12 / 09 / 1949$ & Enrico Gaspar Dutra \\
\hline 5 & Cândido Motta Filho & $13 / 04 / 1956$ & Juscelino Kubitschek \\
\hline 6 & Antônio Martins Villas Boas & $13 / 02 / 1957$ & Juscelino Kubitschek \\
\hline 7 & Antônio Gonçalves de Oliveira & $10 / 02 / 1960$ & Juscelino Kubitschek \\
\hline 8 & Vitor Nunes Leal & $26 / 11 / 1960$ & Juscelino Kubitschek \\
\hline 9 & Pedro Rodovalho Marcondes Chaves & $14 / 04 / 1961$ & Jânio Quadros \\
\hline 10 & Hermes Lima & $11 / 06 / 1963$ & João Goulart \\
\hline 11 & Evandro Cavalcanti Lins e Silva & $14 / 08 / 1963$ & João Goulart \\
\hline
\end{tabular}

Fonte: Elaboração própria.

Recursos, José Aguiar Dias ${ }^{13}$ e o desembargador do TJRJ, Osny Pereira Duarte, posto em disponibilidade por dez anos por Carlos Lacerda, então Governador da Guanabara. Ambos os magistrados constaram da lista de cem nomes que tiveram seus direitos políticos cassados pelo Ato no 1 do Comando Supremo da Revolução, publicado em 10 de abril de 1964, quando foram também cassados Luís Carlos Prestes, João Goulart, Jânio Quadros, Leonel Brizola, Celso Furtado, 41 deputados federais, 29 líderes sindicais, oficiais militares, entre tantos outros. ${ }^{14}$

A exemplo de outras medidas do governo que se instalava, os atos do Comando Supremo da Revolução foram excluídos de apreciação judicial, salvo para "o exame de formalidades extrínsecas, vedada a apreciação dos fatos que o motivaram, bem como da sua conveniência ou oportunidade". Contra a previsão normativa de exclusão do acesso à justiça para a discussão das medidas restritivas de direitos não há registro de pronunciamento do Supremo Tribunal Federal. Igualmente, não houve decisão da Corte relativa à redução das garantias de independência judicial das demais instâncias na fase de instalação da ditadura.

Segundo apurou a Comissão Nacional da Verdade, ${ }^{15}$ o exercício da competência para apreciar os recursos criminais e habeas corpus impetrados em favor de investigados por crimes políticos foi inicialmente marcado por contradiçóes na prática institucional do Supremo. De um lado, o Tribunal não esboçou reação contrária à redução de suas atribuiçôes na arquitetura judicial promovida pelos dois primeiros Atos Institucionais. Por outro, a interpretação adotada na concessão de diversos pedidos de habeas corpus evoluiu no sentido de se desvincular da figura da autoridade coatora (o que impedia a Corte de conhecer HCs impetrados contra militares) e de abranger a análise do ato impugnado, sujeitando ao seu exame casos que originariamente eram de competência do Superior Tribunal Militar. ${ }^{16}$

Da inicial relação de condescendência com a atuação da Corte, marcada pela visita de Castello Branco, à radical interferência na atividade dos ministros após a concessão de alguns habeas corpus a governadores ${ }^{17}$ e outros perseguidos políticos, ${ }^{18}$ não se passou muito tempo. Nas decisóes envolvendo governadores e ex-secretários estaduais, a tensão com os militares residiu na posição do STF em afirmar que os afastamentos violavam o princípio federativo e a prerrogativa de foro para o julgamento (Vale, 1976, p. 66).

A interferência no STF havia sido incentivada em campanha do jornal $O$ Estado de S. Paulo ${ }^{19}$ dias 
após o golpe pelo grupo conservador que apoiou a deposição de João Goulart ao pedir a cassação dos ministros indicados por ele: Evandro Lins e Silva e Hermes Lima. Este havia sido chefe da Casa Civil e ministro do Trabalho no governo Goulart. O próprio Evandro Lins e Silva chegou a admitir que poderia ser cassado no primeiro ato institucional. Porém, ele e Hermes Lima reagiram em carta contra as acusaçóes, entregue a Ribeiro da Costa. Por sua vez, Costa fez uma enérgica defesa dos ministros atacados na sessão de julgamento no plenário do STF, no que foi apoiado por Hahnemann Guimarães e Victor Nunes Leal. Segundo Lins e Silva: “esse episódio nos fortaleceu muito no Tribunal, porque mostrou a solidariedade da instituição conosco. Tanto que, daí por diante, os ataques serenaram" (Lins e Silva, 1997 , p. 381). A intenção de cassar os dois ministros, além de Victor Nunes Leal, acabou sendo revelada mais tarde por Costa e Silva, na 45a sessão do Conselho de Segurança Nacional, em 16 de janeiro de $1969 .{ }^{20} \mathrm{Na}$ reunião, o então presidente afirmou que foi devido à intervenção de Francisco Campos - artífice jurídico dos atos institucionais, para quem o governo deveria "preservar, pelo menos, um dos Poderes", que o Supremo foi poupado no momento inicial do regime. Contudo, já em agosto de 1964, o general Golbery do Couto e Silva via na ampliação da competência da Justiça Militar a alternativa de contenção do Poder Judiciário nos limites da "linha dura" que começava a se desenhar, o que culminaria com a "militarização do processo judicial" (Gaspari, 2002, p. 260).

A percepção de que o STF estava sendo moldado pelos militares para atuar de acordo com as diretrizes do regime foi também evidenciada pela troca de correspondências ${ }^{21}$ entre dois juristas. O primeiro deles, Heráclito Fontoura Sobral Pinto, destacado advogado na defesa dos direitos de perseguidos políticos durante as ditaduras do Estado Novo e militar, além de defensor das prerrogativas da advocacia durante o regime. ${ }^{22} \mathrm{O}$ segundo, José Eduardo Prado Kelly, deputado udenista, que havia sido constituinte em 1946, além de presidente do Conselho Federal da OAB entre 1960-1962, e naquele momento integrava a Comissão formada pelo governo para elaborar o projeto de reforma do Judiciário. Na primeira carta, escrita em 28 de julho de 1965, Sobral Pinto manifesta sua preocupação:

Venho agora à sua presença sob a inspiração de um nobre sentimento: defender o Poder Judiciário, ameaçado pela paixão política daqueles que estão hoje no Poder ou dos que desfrutam a estima do Poder. Tenho profundas mágoas da maioria dos membros do Supremo Tribunal Federal. Não são mágoas de ordem pessoal, mas de alguém que luta pela distribuição da justiça. Vejo, às vezes, o Supremo Tribunal Federal votar em maioria, sob a inspiração de razóes políticas, deixando de lado normas legais e preceitos de justiça aplicáveis às espécies decididas. Revolto-me com as deliberações infelizes. Mas não misturo o erro dos juízes com a estrutura do órgão que encarna o Poder Judiciário em nossa pátria, convencido de que os homens passam e a instituição permanece.

Os políticos e os militares que subiram ao Poder em abril do ano passado querem que a justiça se ponha ao serviço de seus propósitos, de suas ambições ou de seus caprichos. Pretendem, meu caro amigo, conciliar duas causas inconciliáveis: a violência representada pela rebeldia de abril do ano passado, e a justiça que é uma virtude isenta e serena, que tem de dar a cada um aquilo que lhe pertence independentemente de sua raça, de sua posição, de sua fortuna, de suas crenças e de suas ideias.

O pedido de Sobral Pinto consistia na atuação de Prado Kelly para impedir que fosse excluída da competência do Supremo a apreciaçáo de habeas corpus e mandados de segurança. $\mathrm{O}$ pedido, contudo, não surtiu efeito. A grande insatisfação do governo militar com o Supremo se manifestaria cerca de um ano e meio após o golpe, logo em seguida à entrevista concedida por Ribeiro da Costa ${ }^{23}$ em defesa da independência judicial para o controle de legalidade e constitucionalidade dos atos do governo. A repercussão da entrevista nos meios militares provocou a dura resposta de Costa e Silva ao afirmar que: "O exército tem chefe. Não precisa de liçôes do Supremo. [...] Dizem que o Presidente é politicamente 
fraco, mas isso não interessa, pois ele é militarmente forte" ${ }^{24}$ acrescentando que as forças armadas tinham sido aclamadas pelo povo e apenas o povo poderia determinar o seu retorno aos quartéis. A preocupação de Castello em não dividir o Exército foi mais forte que a manutenção da boa relação com Ribeiro da Costa. Então, no dia seguinte, este pediu uma audiência com Geisel, chefe do gabinete militar, e devolveu a Ordem do Mérito Militar dizendo: "Eu não posso mais ficar com isso".

Ainda em reação às declaraçôes de Costa e Silva, Ribeiro da Costa afirmou publicamente que fecharia o Tribunal e mandaria entregar as chaves no Planalto se a "revolução" cassasse algum integrante do STF. O episódio ficou conhecido como o "Caso das Chaves", segundo o contexto descrito por Ézio Pires (Pires, 1979, pp. 87-91). A reação de Ribeiro da Costa se fez sentir entre os demais ministros do STF. Em seu apoio, os ministros alteraram o regimento do Tribunal prorrogando sua gestáo como presidente do Supremo até sua aposentadoria (Oliveira, 2012, p. 38; Queiroz, 2015, pp. 323-342).

$\mathrm{O}$ acirramento do conflito entre o governo e o STF deu-se no conturbado contexto das eleiçóes para governador realizadas em 11 estados, cujo resultado revelou a derrota dos militares no Rio de Janeiro e Minas Gerais, onde venceram Francisco Negrão de Lima e Israel Teixeira, respectivamente, ambos ligados a Juscelino Kubitschek. O fracasso nas urnas e o aumento da pressão da "linha dura" não fizeram Castello Branco recusar-se a assegurar a posse dos eleitos. Porém, buscando moderar as relações entre políticos e militares, em 27 de outubro de 1965, ele editou o Ato Institucional n. 2, definindo que as eleições nos demais estados da federação seriam indiretas, via Colégios Eleitorais, o que possibilitou o resultado desejado pelos militares, até mesmo em virtude da cassação de mandatos de parlamentares opositores ao governo nas Assembleias Legislativas.

No plano político, o ato dissolveu os partidos, estabeleceu eleiçóes indiretas para o sucessor de Castello Branco e instituiu o bipartidarismo dividido entre a Arena, partido de apoio ao governo, e o MDB, lado da oposição consentida. A medida alterou diversas disposiçóes fundamentais da Constituição de 1946, além de simplificar o proce- dimento de reforma constitucional. $\mathrm{O}$ ato marcaria o "nascimento da doutrina do poder constituinte permanente da revolução" (Barbosa, 2012, p. 78).

Coube ao AI-2 promover o enquadramento do Supremo Tribunal Federal. ${ }^{25} \mathrm{O}$ ato aumentou o número de ministros do STF de onze para dezesseis; estabeleceu que os juízes federais e os do antigo Tribunal Federal de Recursos seriam nomeados pelo presidente da República; excluiu de apreciação judicial os atos praticados pelo "Comando Supremo da Revolução e pelo Governo Federal”, assim como os atos de cassação de mandato ou impedimento de parlamentares, governadores e prefeitos; e, por fim, ampliou a competência da Justiça Militar para estendê-la aos civis, inclusive os governadores, na repressão aos crimes "contra a segurança nacional ou as instituiçóes militares", prevalecendo sobre qualquer outra prevista em leis ordinárias. $\mathrm{O}$ ato se propunha a impedir a continuidade da resistência institucional do Supremo às medidas autoritárias, ocasião em que foram nomeados cinco novos ministros, como indicado no Quadro 2.

Como destaca Barbosa, dos cinco novos ministros, quatro tinham relação explícita com os militares (Barbosa, 2012, p. 86). O próprio Prado Kelly, jurista e deputado udenista, além de ex-presidente do partido e presidente da comissão de juristas cujo parecer subsidiou o AI-2; Carlos Medeiros e Silva, que havia auxiliado Francisco Campos na redação da Carta de $1937,{ }^{26}$ além de na redação dos dois primeiros atos institucionais pós-golpe e, num futuro breve, auxiliaria na redação do anteprojeto da Constituição de 1967 na condição de ministro da Justiça; Oswaldo Trigueiro era Procurador-Geral da República, além de ex-governador e deputado udenista; Aliomar Baleeiro era um dos mais ferozes críticos do governo Goulart e deputado udenista pela Guanabara, e, por último, Adalício Nogueira, juiz de carreira e acadêmico. Este, segundo Barbosa, era o que menos relaçóes mantinha com os militares.

A nomeação de Prado Kelly foi vista com decepção por Sobral Pinto que havia se oposto claramente contra a edição do AI-2. ${ }^{27}$ Então, em 3 de novembro de 1965, novamente escreveu-lhe uma carta elencando uma série de motivos pelos quais Kelly não deveria ter aceitado o convite. Entre eles, estavam o fato de o Supremo ter se posicionado 
Quadro 2

Ministros Nomeados para Preencher as Vagas Criadas com o AI-2 (16/11/1965)

\begin{tabular}{ll}
\hline & Nome \\
\hline 1 & Adalício Coelho Nogueira \\
\hline 2 & José Eduardo do Prado Kelly \\
\hline 3 & Oswaldo Trigueiro de Albuquerque Mello \\
\hline 4 & Aliomar de Andrade Baleeiro \\
\hline 5 & Carlos Medeiros Silva \\
\hline
\end{tabular}

Fonte: Elaboração própria.

categoricamente contra a majoração de seus membros; de Kelly ter sido escolhido justamente em ato de violação à independência da Corte e do Judiciário, com a suspensão simultânea da vitaliciedade e inamovibilidade da magistratura; de a nomeação ter sido promovida em retaliação à atuação de cinco ministros nomeados por Kubitscheck e Goulart, que se recusariam servir à "Revolução", o que estava claro na declaração do então ministro da Justiça Juracy Magalhães - "ou aumentar 5 ministros ou tirar 5". Sobral Pinto invocou a situação de que o próprio pai de Prado Kelly, o ex-ministro do STF Octávio Kelly, ter sido intimidado e instado a se aposentar durante o Estado Novo, também por efeito da "paixão política, inspiradora da atual hostilidade ao Supremo Tribunal Federal".

A carta foi respondida por Prado Kelly no dia seguinte, quando alegou ter contrariado sua vontade pessoal para seguir razóes de ordem nacional, além da "esperança de servir ao país e à nossa classe (dos juristas)". Sobre o elenco das denúncias de Sobral Pinto, o ministro recém-nomeado não se pronunciou, mas apresentou uma justificativa técnica para a elevação do número de integrantes na reforma de que tinha participado enquanto membro da Comissão: "a imprescindível formação de uma terceira turma, para dar vazão ao saldo copioso dos recursos extraordinários, cujo vulto, como se frisou, excede aos 50.000 , e que tenderá pela progressão demográfica, a ultrapassar em muito os índices anuais até hoje registrados" ${ }^{28}$

Dias depois, o Congresso Nacional aprovava a Emenda Constitucional n. 16, de 26 de novembro de 1965 , que instituía a representação de incons- titucionalidade, primeiro instrumento de controle concentrado de constitucionalidade, com legitimação ativa exclusiva ao procurador-geral da República, cargo de confiança do governo. A medida evidenciava mais um passo da dupla centralização política $^{29}$ (no Executivo, no âmbito dos poderes, e na União, no âmbito federativo), com a ampliação do controle sobre os estados.

Internamente, a nomeação dos cinco novos ministros não parece ter causado grande impacto no perfil das decisóes do STF. Segundo Lins e Silva $(1997$, p. 393), os nomeados foram bem recebidos e logo passaram a votar "absolutamente de acordo” com os veteranos nos processos políticos. Outro ponto que diluiu a influência do regime com as nomeações foi a organização dos trabalhos da Corte. Antes dividida em duas turmas com cinco ministros cada, a divisão interna passou a contar com três turmas de cinco membros, sendo que dois dos novos ministros ocuparam a primeira turma; dois integraram a segunda e um teve lugar na terceira. Tal configuração na distribuição dos novos ministros nas turmas desenhou um quadro em que eles nunca pudessem formar maioria em qualquer delas.

\section{Negociando as condiçóes políticas da independência judicial}

A nomeação dos novos ministros e a aprovação da reforma do Judiciário, que alterava substancialmente as funções do STF e o controle de constitucionalidade no país sem consulta aos integrantes 
da Corte, contudo, não foi capaz de romper as relações institucionais entre o Tribunal e o governo militar. É o que se observa no discurso que recorre à neutralidade política, feito pelo ministro Antônio Gonçalves de Oliveira, vice-presidente do Supremo, em 13 de março de 1967, quando recebeu a visita de despedida de Castello Branco, cujo mandato terminaria dois dias depois:

É com grande honra que recebemos a visita de Vossa Excelência a esta Casa. Registramos, a propósito, que Vossa Excelência, a primeira vez que saiu oficialmente de seu Palácio, como Presidente da República, foi para uma visita a esta Corte de Justiça. Vossa Excelência, então, manifestava o apreço do Chefe do Executivo ao Supremo Tribunal Federal. Causa-nos, assim, justo orgulho esta segunda visita, três anos após, uma das últimas, que faz, como chefe do governo, cujo mandato findar-se-á a 15 do corrente. Este Tribunal não terá desmerecido do apreço então externado por Vossa Excelência. Todos sabemos que não é fácil harmonizar a ordem política com os programas e propósitos revolucionários. No fervilhar das paixões, nós, os Juízes, nem sempre somos compreendidos. É que, no exercício de nossas funções, não podemos ficar a favor, nem contra, precisamente porque somos Juízes, escravos da Lei, que juramos cumprir e de acordo com a qual julgamos (Gonçalves de Oliveira, 1968, pp. 5354, destaques meus).

As consideraçóes do ministro foram reiteradas por Castello Branco ao afirmar ter ouvido de um jurista brasileiro que, em situação de crise, "não é possível haver juízes revolucionários; o que é possível é haver leis revolucionárias". No discurso do general estava presente a ideia de ter conferido ao STF mais autonomia, num passo rumo à evolução da Corte. Um "traço revolucionário" a ser assegurado pelo projeto de constituição que resultaria na Carta de 1967, cuja redação não trouxe inovaçóes substanciais sobre a organização interna do Judiciário, ${ }^{30}$ mas que avançou em direção à concentração da jurisdição constitucional no âmbito do Supremo Tribunal Federal. ${ }^{31}$
No entanto, uma das alteraçóes na organização do Judiciário promovidas pelo texto constitucional de 1967 chegou ao Supremo Tribunal Federal. ${ }^{32} \mathrm{O}$ art. 118 da Constituição mudou a forma de nomeação dos juízes da Justiça Federal, que havia sido recriada com o AI- $2^{33}$ e organizada pela lei n. $5.010 / 1966$, prevendo a nomeação por decreto presidencial a partir de lista quíntupla elaborada pelo STF. ${ }^{34}$ Segundo a nova regra, a nomeação deveria recair sobre brasileiros maiores de 30 anos, de cultura e idoneidade moral, mediante concurso de títulos e provas organizado pelo Tribunal Federal de Recursos.

Quando já havia entrado em vigência a disposição do art. 118 da Constituição de 1967, juízes aprovados como substitutos pleitearam a nomeação para cargos de juiz federal para a Seção Judiciária de São Paulo, mas foram preteridos por juízes não concursados. O grupo ajuizou o Mandado de Segurança n. 19.873/SP, questionando o ato de nomeação do presidente da República, general Costa e Silva, realizado de acordo com as regras revogadas do AI-2 e da lei n. 5.010/1966, que não exigiam a prévia aprovação em concurso público.

A ação foi relatada pelo ministro Themístocles Cavalcanti que, no julgamento realizado em 22 de junho de 1968, denegou a segurança. Cavalcanti entendeu serem aplicáveis os incisos I e III do art. 173 da Constituição de 1967, que, ao dispor sobre as regras gerais e transitórias, excluiu de apreciação judicial os atos praticados pelo Comando Supremo da Revolução, além dos consubstanciados nos atos institucionais ou deles derivados. A decisão assegurava que, apesar de praticado após o início da vigência da Constituição, o ato de nomeação editado em desacordo com a exigência do concurso público seria alcançado pela abrangência dos dispositivos revogados, posto que as nomeaçóes do presidente teriam passado pelo crivo do Senado Federal, atendendo ao requisito normativo anteriormente vigente.

A decisão foi seguida pela maioria do Tribunal, vencidos os ministros Evandro Lins e Silva, Hermes Lima e Victor Nunes Leal, que acolhiam a alegação de incompatibilidade da nomeação dos juízes federais sem concurso com o texto constitucional. O resultado do julgamento é um bom exemplo de como as garantias de independência da magistratura 
passaram a ajustar-se às mudanças impostas pelo autoritarismo ao desenho institucional do Judiciário. ${ }^{35}$

Entretanto, a complexidade de tal ajuste envolvia certo grau de autonomia do STF na defesa ou manutenção do desenho institucional e do governo perante o Poder Judiciário. No sentido de assegurar a autonomia dos tribunais para fixar as regras sobre provimento dos cargos da magistratura, a Representação no 749/RS foi julgada improcedente em 4 de dezembro de 1968. A ação pleiteava a inconstitucionalidade de disposição da Constituição gaúcha que criava a carreira de "juiz substituto" e, assim, postergava a vitaliciedade. Contudo, ao decidir, o STF manteve a competência do governo estadual em disciplinar a organização do Judiciário e rejeitou os pedidos da Procuradoria-Geral da República. ${ }^{36}$ Contrariando a pretensão de autonomia dos tribunais, o julgamento da Representação no 746, que contrariou a regra da Constituição do Estado da Guanabara no sentido de atribuir ao Tribunal de Justiça a iniciativa de lei para propor à Assembleia Legislativa a fixação de vencimentos dos magistrados e servidores. ${ }^{37}$ Novamente o STF manteve a competência da chefia do Executivo estadual em simetria ao modelo federal.

A interferência do governo militar na autonomia do Judiciário se observava também na tentativa de impedir que advogados considerados "subversivos" se tornassem magistrados. Um caso que testou os limites da tensão entre o STF e o governo nesse quesito foi o julgamento do MS n. 18.972/ DF, ${ }^{38}$ impetrado por Olga Gomes Cavalheiro. Ela havia sido aprovada em $18^{\circ}$ lugar no concurso para a magistratura trabalhista no TRT do Rio Grande do Sul, realizado em 1964. Contudo, teve negado o direito à nomeação, mesmo quando já nomeados os candidatos classificados nas últimas colocaçóes ( $19^{\circ}$ ao $24^{\circ}$ lugares), sob o argumento de que o presidente da República não estava vinculado à ordem de classificação do concurso, podendo escolher entre os indicados na lista tríplice oferecida pelo Tribunal local. Travou-se, então, uma longa discussão na sessão de julgamento, do dia 11 de setembro de 1968, que entendeu que o único critério legal para a nomeação era a classificação do concurso, independentemente da lista tríplice. $\mathrm{O}$ voto do ministro Eloy da Rocha concluiu que o decreto-lei n. 229/1967 havia alterado dispositivos da CLT relativos ao ingresso na magistratura, conduzindo a unanimidade do Tribunal a conceder a segurança.

Apesar de não discutida entre os fundamentos da decisão, a provável causa da rejeição de Costa e Silva em nomear Olga Cavalheiro estava na sua descrição como "comunista" e "ligada a elementos esquerdistas e comunistas" registrada na ficha mantida pelo Conselho Nacional de Segurança. Mantendo sua posição, mesmo após a decisão do STF, Costa e Silva decidiu cassar-lhe os direitos políticos. Nas suas palavras, era a "única forma de evitar que ela seja sancionada agora, cassando os direitos políticos e assim ela não poderá ser nomeada juiz". No que foi apoiado pelo entấo ministro da Justiça Gama e Silva: "[a] prova da atividade comunista é grande. É pena que ela seja bacharela. É comunista militante".$^{39}$ Os direitos políticos de Olga Cavalheiro foram cassados por dez anos após deliberação da 49o sessão do Conselho de Segurança Nacional, em 1 de julho de 1969.

No plano das relaçóes entre o Supremo e os militares, parecia prevalecer uma relação de condescendência mútua que marcava a cumplicidade de alguns ministros na função de direção da Corte com a ditadura. Nessa relação, o discurso de pleno vigor da independência judicial ocupou espaço relevante, ainda que a prática do STF fosse vacilante sobre a autonomia dos demais órgãos do Judiciário. Se entre os militares e os ministros do Supremo a tensão parecia, de algum modo, mantida sob controle, no plano interno da caserna a percepção era de que o Poder Judiciário era uma ameaça ao regime, em virtude do seu potencial desmoralizador para o governo, em especial pela sua atuação em sede de habeas corpus. Nesse sentido, o curso promovido pela Escola Superior de Guerra em 1969 registrava:

O Judiciário. A infiltração nesse Poder confere aos comunistas uma garantia de impunidade crescente, permitindo-lhes uma situação cada vez mais ostensiva e desafiadora, o que muito concorre para desmoralizar o governo. Um ruidoso "habeas-corpus", habilmente explorado, não só irrita e desencoraja a população que se vê à mercê da subversão, como desestimula e desmoraliza os agentes da Lei. ${ }^{40}$ 
Em 12 de dezembro de 1968, um dia antes da edição do AI-5, na sessáo solene de transmissáo da presidência do ministro Luiz Gallotti a Gonçalves de Oliveira, o primeiro destacou que durante sua gestão a relação com os outros poderes havia sido harmoniosamente mantida, sem prejuízo da independência. Já Oliveira destacava o fato de a Corte atravessar uma "fase crítica de sua história", porém, para relacionar as expressóes crítica e história à sobrecarga de processos nos gabinetes dos ministros. Na sua visão, o Tribunal continuaria a julgar de modo independente como sempre havia julgado, sem pressóes de qualquer espécie. ${ }^{41}$

No dia seguinte, a consolidação do autoritarismo sobre as funçóes do Supremo ${ }^{42}$ foi reforçada pelo Ato Institucional n._5, ao qual se seguiu a aposentadoria forçada dos Ministros Victor Nunes Leal, Hermes Lima e Evandro Lins e Silva, no mês de janeiro de 1969. Sobre o decreto de aposentadoria, registrou Hermes Lima em suas memórias:

Fui o terceiro juiz aposentado pelo Ato Institucional n. 5. Essas aposentadorias, cinco anos depois de deflagrada a revolução, remataram obstinada campanha de índole política discriminatória que inicialmente visou a Evandro e a $\mathrm{mim}$, acabou colhendo Victor Nunes Leal e, por pouco, não atingiu outros ministros. Sem dúvida, repercutiram fundamente na maioria judiciária que, embora silenciosa, sentiu, mais uma vez, o drama das depuraçóes políticas de juízes em épocas revolucionárias. Mas, no Tribunal do Estado da Paraíba, em sessão plena, levantou a voz o desembargador Emílio de Farias, que, evocando Calderon de la Barca: "Dê-se tudo ao rei, menos a honra" - disse a seus pares. "Eu mentiria a mim mesmo, que é a forma mais vergonhosa de mentir, se por conveniência ou pusilanimidade silenciasse ante a perda irreparável que sofreram a magistratura e a cultura jurídica do Brasil com o afastamento compulsório das atividades judicativas de tâo eminentes jurisconsultos patrícios". Foi logo em seguida aposentado (Lima, 1974, pp. 289-290).

Após serem pressionados por Costa e Silva, aposentaram-se os Ministros Gonçalves de Oliveira, entấo presidente, e Lafayette de Andrada, a quem caberia assumir o seu lugar. ${ }^{43}$ Além do impacto sobre o STF, o AI-5 suspendeu os habeas corpus relativos aos crimes políticos, viabilizou demissóes e aposentadorias de magistrados, que tiveram suspensas suas garantias de inamovibilidade e vitaliciedade. Sob o ato, prisóes sem mandato judicial e acusação formal se intensificaram, sem que advogados pudessem buscar na jurisdiçáo civil a proteção dos direitos de opositores do governo.

Com a edição do Ato Institucional n. 6, de 1 de fevereiro de 1969, que reduziu o número de ministros de 16 para 11, a composiçáo do STF passou a contar apenas com Luiz Gallotti, que não havia sido nomeado pelo regime. Gallotti assumiu novamente a presidência do Supremo em caráter provisório, razâo pela qual recebeu as críticas de Sobral Pinto, cuja posição era de que a única saída honrosa a ser tomada seria a renúncia de todos os ministros da Suprema Corte (Dulles, 2007, p. 161).

$\mathrm{Na}$ fase posterior ao AI-6, as manifestaçóes públicas dos ministros eram marcadas pela tolerância ao regime e a exaltação da independência da toga era identificada como qualidade moral do caráter do magistrado ${ }^{44}$ e náo como prerrogativa a ser reconhecida e respeitada pelo poder dos militares. Em 1968, a função política do tribunal era reconhecida e descrita pelo ministro Aliomar Baleeiro em termos de fazer prevalecer a opção política da Constituição sobre todos os desvios do Executivo ou Legislativo. Logo, os "freios, aceleradores e amortecedores constitucionais estão entregues à prudência do Supremo Tribunal Federal, que, inevitavelmente, há de refletir os julgamentos de valor e as opçóes formadoras da educação e do espírito de seus membros" (Baleeiro, 1968, p. 103; ver tb. Oliveira, 2004, p. 108). Posição semelhante foi descrita por Evandro Lins e Silva, que destacou a fidelidade do STF à Constituição negando, contudo, que a Corte tivesse se posicionado contra os militares (Lins e Silva, 1997, p. 386).

Todavia, a defesa da postura dos ministros em relação aos militares não pareceu suficiente para a garantia da independência judicial no Tribunal. Após o AI-5, a Corte havia deixado de ser um órgáo da soberania nacional e passado a subordinar-se ao presidente da República. Segundo Lins e Silva 
(1997, p. 407), o STF havia sido "castrado no seu poder de órgão que compóe o sistema dos três poderes independentes e harmônicos entre si”. O aumento de competências que algumas das reformas legislativas conferiu ao STF não havia lhe concedido poder suficiente para afirmar a Constituição contra as medidas autoritárias do Executivo. Essa carência passava a se refletir nos julgamentos, a exemplo do acolhimento da constitucionalidade da lei de censura prévia editada por Médici em 1971 pelo Tribunal, contra o voto isolado de Adauto Lúcio Cardoso, que abandonou o plenário em seguida. Nessa linha, verifica-se a posição de Victor Nunes Leal, em palestra proferida no ano de 1980, quando registrou a incompreensão dos militares sobre o papel da Corte e o recrudescimento do regime em relação ao Tribunal:

Naqueles primeiros anos da Revolução de 1964 não havia, em algumas áreas do Governo, a nítida compreensão - ou aceitação - de que o papel do Supremo Tribunal Federal não era interpretar as normas constitucionais, institucionais ou legais de acordo com o pensamento ou interesse revolucionário, mas interpretá-las consoante o seu próprio entendimento. Havia reservas, menos ou mais explícitas, à independência do Judiciário [...] Mais tarde, certamente, o sistema jurídico da Revolução se foi desdobrando para cobrir a superfície até então ocupada pelo direito anterior, que era de inspiração liberal. E também se ampliaram as situações em relação às quais ficou obstada a apreciação judiciária de atos do Governo (Leal, 1999, pp. 267-268)

Ao tratar das restriçóes aos magistrados, Baleeiro sugere uma equivalência entre apartidarismo e neutralidade política, afirmando que "qualquer ativismo partidário prejudicaria o dever de imparcialidade na aplicação da Constituição, para solução daqueles atritos sociais, que são normalmente levados à balança da Justiça. A fim de que os pese e decida”. ${ }^{45}$ Já em relação ao que denominou de "impacto da Revolução sobre o STF”, Baleeiro absteve-se de avaliá-la enquanto fato político ao dizer que "ninguém pode ser historiador dos fatos de seu tempo, mormente quando neles, além de testemunha, algumas vezes se desempenhou o papel de corista humilde, entre os solistas e regentes da orquestra" (Baleeiro, 1968, p. 131).

Mesmo tendo desempenhado o mandato de deputado pela UDN e ascendido ao Tribunal por relaçóes políticas com os militares, em texto publicado em 1972, Aliomar Baleeiro condenou a figura do "juiz partidário" e designou como 'horror' a justiça política. Nas palavras do ministro, o mecanismo era uma deturpação para "a consecução de objetivos partidários ou determinado e específico programa político com sacrifício do ideal de imparcialidade e nobreza do aparelho judicial" (Baleeiro, 1972, p. 6). No entanto, realizando juízo técnico ${ }^{46}$ a partir das estatísticas de julgamento do Tribunal entre 1965 e 1966, concluiu que o sucesso do movimento militar era evidente, pois se havia registrado a melhora de rendimento em $90 \%$ na Corte.

A avaliação da eficiência técnica do Supremo na comunicação entre Judiciário e Executivo na ditadura militar incorporava-se no plano das relaçóes institucionais, das quais dependiam os próprios ministros para exercerem suas atividades. A sintonia do diálogo entre Geisel e o STF poderia ser atribuída ao objetivo de promover maior estabilidade institucional e previsibilidade política ao regime (Codato, 2005, p. 84 e 94), acompanhada da afirmação de Geisel de iniciar uma transição "lenta, gradual e segura". Contudo, a derrota da Arena nas eleiçóes gerais de 1974, primeiro ano do governo, que renovou um terço do Senado e toda a Câmara dos Deputados, retirou a maioria de dois terços do Congresso, provocando uma mudança nos planos.

Em 1975, o STF havia elaborado um detalhado diagnóstico do seu funcionamento e o encaminhou ao Presidente Ernesto Geisel. ${ }^{47} \mathrm{O}$ relatório continha dados da sobrecarga e informava a crise de morosidade nos julgamentos, a dificuldade no recrutamento de bons juízes, a defasagem remuneratória e a necessidade de adoção de uma Lei Orgânica da Magistratura Nacional. A fase era de aproximação entre os ministros e o Executivo, representado pelo ministro da Justiça Armando Falcão, que coordenou o projeto de Reforma do Judiciário, encaminhado pelo governo ao Congresso.

Mas o resultado das eleições de 1974 havia conferido ao MDB poder suficiente para travar as 
reformas constitucionais, entre elas a do Judiciário. O comando emedebista negociava com o governo os termos do projeto e ofertou como contraproposta "o restabelecimento das garantias que o AI-5 tirou dos juízes e dos tribunais e do princípio do habeas-corpus para proteger acusados de crimes políticos" ${ }^{48}$ Contudo, a contraproposta não foi aceita pelo governo. Ulysses Guimarães, Tancredo Neves e Thales Ramalho, líderes moderados do MDB, chegaram a defender a aceitação da proposta do governo como forma de capitalizar o apoio da Arena para futuras reformas institucionais vistas como mais significativas. Mas o diretório não acolheu a ideia de que votar contra a reforma do Judiciário seria evitar "um prematuro e inútil confronto com o governo". Venceu a corrente levantada pelo Senador Paulo Brossard fechando a posição do partido contra a aprovação do projeto enviado por Geisel.

A rejeição do projeto de reforma do Judiciário pelo MDB desencadeou a brusca reviravolta de Geisel em direção ao autoritarismo. Ao saber da derrota no Congresso, o governo resolveu baixar o "pacote de abril". A medida não escondia seu objetivo eleitoral. A previsão de eleiçóes diretas para governadores estaduais em 1978 tornou-se um virtual problema para os militares, agravado pela perda de espaço no Legislativo para alterar o quadro. Então, em $1^{\circ}$ de abril de 1977 , Geisel fechou o Congresso por 14 dias e estabeleceu, por meio de seis decretos-lei, um conjunto de reformas. Entre elas: o aumento do mandato presidencial de cinco para seis anos; a alteração do quórum de aprovação das emendas constitucionais para maioria simples; a instituição de eleiçóes indiretas para governadores e um terço do Senado (os "biônicos"); a ampliação de bancadas em que a Arena tinha resultados eleitorais mais favoráveis e a extensão da Lei Falcão ${ }^{49}$ às eleições estaduais e federais.

A medida também aprovara a reforma do Judiciário causando profundo impacto na burocracia judicial. Foi criado o contencioso administrativo para as relações de trabalho de servidores com a União e instituíram-se a avocatória e a representação interpretativa, além do Conselho Nacional de Magistratura. A reforma foi duramente criticada entre os juristas militantes e defensores de perseguidos pelo regime. ${ }^{50}$ As principais objeçóes ao autoritarismo da reforma vieram da oposição política ao regime no
Congresso, a exemplo do discurso de Paulo Brossard, já no cenário da incipiente abertura (Paixão e Barbosa, 2008, p. 122).

Nas conferências realizadas na Universidade de Brasília, entre 11 e 14 de setembro de 1978, por ocasião da comemoração do Sesquicentenário do STF, o ministro da Corte, José Pereira Lira, defendia o afastamento dos modelos constitucionais de 1891, 1934 e 1946 naquele momento do contexto de institucionalização da reforma do Judiciário: "[a] tarefa do momento reclama o armar o Estado de poderes excepcionais - como, aliás, em todos os continentes -, e passageiros no tempo e conformes com as circunstâncias que mudaram e quem sabe se não tornarão a mudar". ${ }^{51}$ Numa interpretação contraditória, mas politicamente funcional, Lira entendia o papel do STF enquanto poder moderador de supremo intérprete, em cuja manifestação se incorporava a vontade do povo, associado à "roda mestra" da maquinaria do regime, sobre o qual não faltava o elogio. ${ }^{52}$

Para Koerner (2010, p. 313), a análise das representações de inconstitucionalidade pós1964 indica que essa avaliação do ministro José Pereira Lira era minoritária entre os demais membros do Tribunal. A assimetria no exercício dos poderes era patente e contava com a postura austera de autocontenção dos próprios ministros, que evitavam dar declaraçóes na imprensa especialmente diante de casos com potencial repercussão política - mesmo quando já esgotado o regime militar e no curso da transição. Esse era um modelo de comportamento consentâneo com a ampliação das atribuiçóes de controle concentrado no Supremo, com composição já majoritariamente redefinida pelo regime militar, quando o Tribunal passaria a julgar representaçóes também contra as leis aprovadas pelo Congresso Nacional e não apenas pelos Estados.

Porém, a compreensão do papel do STF e da independência do Judiciário enquanto consectários da defesa da ordem e não das expectativas de justiça ou de demandas por igualdade também era expressamente asseverada no discurso oficial da Corte. $\mathrm{Na}$ sessão solene do dia 18 de setembro de 1978, também em comemoração ao Sesquicentenário, o presidente do Tribunal, ministro Thomp- 
son Flores ${ }^{53}$, fez um longo apanhado histórico da vida institucional do STF. No seu pronunciamento: "o Supremo Tribunal Federal se manteve sempre independente e imparcial. Seus juízes em todos os tempos julgaram como entendiam em sua consciência, de direito e justiça”. E, negando a função política da Corte, absteve-se de qualquer crítica para descrever a EC n. 7/1977 como acertada opção técnica, externando a sua concordância com a posição do ministro Oswaldo Trigueiro ao reproduzir o seguinte trecho: "Dizer-se que o Supremo Tribunal sempre esteve a favor das forças dominantes é menos um juízo crítico do que a constatação de uma contingência inelutável. Toda ordem jurídica reflete, necessariamente, as condiçóes dominantes em determinado momento político e social. A missão dos Tribunais não é outra senão a de defender a ordem estabelecida, aplicando leis que não são feitas por eles".

A percepção de que os militares tinham alcançado a imposição hegemônica do seu domínio sobre as instituições judiciais não se repete quando se dirige a análise ao plano das ideias políticas em disputa naquele momento. A resistência dos grupos de intelectuais, artistas, profissionais liberais, estudantes, a dissidência católica ligada à teologia da libertação e os partidos de esquerda isolados da institucionalidade, havia sido responsável pela manutenção de uma reserva crítica influente e, em alguma medida, autônoma nos primeiros anos do regime (1964-1968). ${ }^{54}$

$\mathrm{O}$ endurecimento da repressão havia provocado o exílio de muitos dos membros dessa resistência intelectual e acadêmica que, no entanto, passou a falar mais para si mesma após as falhas nas tentativas da desejada ampliação do seu campo de influência contestadora sobre a população. Tal condição limitadora da livre circulação de ideias ocorreu simultaneamente à expansão da fragmentação de correntes do pensamento social no Brasil, o crescimento dos cursos de pós-graduação e a profissionalização acadêmica nas ciências sociais (Pécaut, 1990 , p. 253 e 261), por um lado. E, por outro, a reuniāo daqueles diversos grupos da resistência com interesses os mais distintos - porém, autoidentificados na luta contra o autoritarismo -, em torno na reorganização da sociedade civil que passava a ser vista como a única alternativa viável para a superação do regime militar.

Segundo Pécaut, essa aparente contradição entre a divisão de correntes e a aliança pragmática com outros setores foi em parte responsável pela redefinição da imagem de intelectuais e juristas enquanto atores políticos. Crescia a importância dos civis na conformação do regime, cuja transição planejada para ser controlada pelo governo adquiria uma lógica própria no final dos anos de 1970, inclusive eleitoral (Codato, 2005, p. 95). Após a vitória da oposição (MDB) em alguns Estados nas eleições de 1982, alguns daqueles atores voltaram a ocupar cargos na alta burocracia estatal, quando já se articulava discursivamente as reivindicaçóes pelas eleições diretas e a convocaçáo da constituinte. Nesse movimento, incluíram-se a SBPC, a ABI e a $\mathrm{OAB}$, esta última aliando a defesa do interesse corporativo da advocacia, que tinha perdido espaço com a redução ou até exclusão de competências do Judiciário pela EC n. 77, com a defesa dos direitos humanos e o restabelecimento do regime democrático (Pécaut, 1990, p. 279).

\section{Consideraçóes finais}

A variação da intervenção dos governos autoritários no desenho institucional do Poder Judiciário pode ser conduzida ao grau de consenso entre as elites judiciais e militares. Esta observação ganha potencial explicativo quando consideramos que durante o regime autoritário a independência do Judiciário exerceu uma função ambígua, colocando-se entre a limitação da coação e a legitimação do seu uso contra os opositores (Pereira, 2005, p. 41; Lemos, 2004). Assim, o fato de ter sido mantido em funcionamento sem uma subordinação explícita ao governo sugeria a vigência do Estado de Direito. E, por sua vez, abre espaço para distinguir ao menos três momentos relevantes sobre o sentido da independência judicial no STF durante a ditadura militar.

No primeiro deles, compreendido entre o período imediatamente anterior ao golpe e até a edição do AI-2, em 16 de novembro de 1965, o consenso entre as elites judiciais e militares parecia consistente, a considerar pela confluência dos discursos 
entre os representantes do Judiciário e do Executivo sobre a importância da manutenção da plena autonomia do STF; confluência marcada pela visita de Castello Branco logo após a deposição de Goulart.

Já o segundo momento, que pode ser observado entre o AI-2 e o AI-5, de 13 de dezembro de 1968, foi caracterizado pela precarização daquele consenso quando, ainda na fase de institucionalização do governo militar, a composição do Tribunal foi modificada à sua revelia e lhe foi subtraída a competência para o julgamento dos atos praticados pelo governo ao passo da ampliação da jurisdição militar. Esse momento teve seu ponto culminante de interferência com a suspensão do habeas corpus, além da decretação da aposentadoria compulsória de três ministros em janeiro de 1969.

No último período analisado, que abrange do impacto do AI-5 até a edição da EC n. 7/1977 e o início da abertura política, notou-se um realinhamento de posições entre as elites militar e judicial. Para tanto, a exclusiva composição da Corte por ministros indicados pelo regime teve um papel fundamental, porém não único. A presença do caráter conservador na formação jurídica dos integrantes do Supremo passou a justificar o discurso de que à magistratura cabia apenas o papel técnico de assegurar a ordem estabelecida. Entretanto, tal posição se articulava contraditoriamente com a noção de que a independência judicial se manifestava em atributos da moral no comportamento individual dos juízes e não na institucionalização de garantias do exercício autônomo da jurisdição.

Esse breve histórico de como o sentido da atividade judicial foi construído na relação entre os juristas e os militares, quando a independência da magistratura foi em parte suprimida e as expectativas de imparcialidade do STF no julgamento de conflitos políticos pareciam inexistentes, ajuda-nos a pensar a experiência que configurou o passado imediato à instalação da constituinte. ${ }^{55}$ Mais ainda, ajuda-nos a compreender a participação de integrantes do Poder Judiciário nos trabalhos da Assembleia Nacional Constituinte, formalmente convocada pela Emenda Constitucional no $26 / 1985$, e que se inseriu no campo mais amplo da distensão de poder dos militares enquanto processo de mediação da nossa transição caracterizada pela permanência de mecanismos institucionais autoritários.

\section{Notas}

1 Sobre os conceitos antitético-assimétricos e o risco de confundir história política com linguagem conceitual como método histórico: Koselleck (2006, pp. 191 197; 2012, pp. 9-26).

2 Díaz-Asensio (2012, pp. 41-44), cujo levantamento estatístico das condiçôes da atuação judicial em ditaduras entre 1972 a 2002 mostrou que regimes autoritários tendem a tolerar a atividade das instituiçóes judiciais em países em que o governo enfrenta uma oposição política organizada do que naqueles onde a elite política se encontra coesa. A expectativa que motivaria a criação de novas cortes ou reforma das existentes seria a de que os juízes pudessem legitimar os efeitos do forte dissenso de certas decisões políticas do regime. No mesmo sentido: Ginsburg e Moustafa (2008, p. 4 e ss.), acrescentando as funçóes de compliance entre governo e burocracia na coordenação das disputas entre facçóes rivais do regime e a oferta de credibilidade para o comércio e investimentos.

3 Além do levantamento bibliográfico relativo à produção jurídica sobre independência judicial e organização do sistema de justiça durante da ditadura, foram coletadas decisóes do STF disponíveis nos repertórios de jurisprudência à época e as disponibilizadas no próprio sítio eletrônico do Tribunal (<www.stf.jus.br>). Como apoio, também foram utilizadas fontes disponíveis no Arquivo Nacional, nas publicaçóes oficiais dos governos militares e no relatório da Comissão Nacional da Verdade.

4 Conceito desenvolvido por Linz (1973, p. 249). Para uma descrição mais ampla das características dos regimes burocrático-militares na tipologia dos regimes autoritários: Linz (1979, pp. 149-169). Também: O’Donnell (1979, p. 85 e ss.), que classifica as ditaduras inauguradas no Brasil em 1964 e na Argentina em 1966 entre os regimes autoritário-burocráticos emergentes da alta industrialização tardia, baseados na coalizão entre setores de cúpula da burocracia e grandes proprietários contra o campesinato e a crescente classe operária urbana, minimizando as possibilidades de uma revoluçáo social.

5 Pereira (2005, p. 34). Sobre a inserção do Judiciário na dinâmica combinação de elementos de exceçáo com a legalidade herdada da Constituição de 1946, tornando mais flexível a administração de conflitos enquanto reduzia o desgaste dos militares entre 1964 a 1969: Lemos (2004, pp. 409-438).

6 Nesse sentido: Miguel Reale (então secretário de Justiça de São Paulo); Vicente Ráo (ex-ministro da Justiça 
e das Relaçóes Exteriores) e Basileu Garcia (professor da USP), este último lançando expectativas de que "o Poder Judiciário há de compreender e legitimar o ato institucional como decorrência do estado de necessidade para salvação da pátria" (publicado em $O$ Globo, de 14/04/1964).

7 Telles Júnior (1965). Autor da conhecida "Carta aos brasileiros", lida no pátio da Faculdade de Direito da USP em 8 de agosto de 1977, que, em contradição ao ato anterior de apoio ao golpe, simbolizou o manifesto do jurista pelo retorno do Estado de Direito: "Consideramos ilegítimas as leis não nascidas do seio da coletividade, não confeccionadas em conformidade com os processos prefixados pelos Representantes do Povo, mas baixadas de cima, como carga descida da ponta de um cabo. Afirmamos, portanto, que há uma ordem jurídica legítima e uma ordem jurídica ilegítima. A ordem imposta, vinda de cima para baixo, é ordem ilegítima. Ela é ilegítima porque, antes mais nada, ilegítima é a sua origem. Somente é legítima a ordem que nasce, que tem raízes, que brota, da própria vida, do próprio seio do povo [...] Afirmamos que o binômio Segurança e Desenvolvimento não tem o condáo de transformar uma ditadura numa democracia, um Estado de fato num Estado de direito". Ver Telles Júnior (1977, pp. 413 e 420). A carta costuma ser referência no discurso dos juristas como ato de engajamento pela democracia, mas o apoio de Telles Júnior ao golpe segue esquecido.

8 Seguida da defesa de que "[p]ode um governo, injusto por sua origem, tornar-se justo por seu funcionamento e redimir-se. Um governo imposto pelas armas ou pela astúcia pode tornar-se, por sua açáo, órgão do poder legítimo. [...] Em consequência, ilegítima será a resistência violenta a um tal governo". Ver Telles Júnior (1965, pp. 94-105 e 117).

9 Nesse sentido, o seguinte trecho do voto de Chaves: "A mim, ao contrário, acho que eram os gorilas aqueles que queriam fazer da nossa independência, da nossa liberdade de opiniáo, do nosso direito de sermos brasileiros e democratas, tábula rasa, para transformar-nos em colônia soviética, onde eles não seriam capazes de manifestar um pensamento sequer em favor das ideias liberais, para eles, então, haveria Sibéria, paredón e outros constrangimentos".

10 Trecho do voto do ministro Pedro Chaves. STF. HC n. 40.910/PE, rel. min. Hahnemann Guimaráes, J. 24/08/1964.

11 Essa imagem foi inscrita logo no parágrafo inicial do primeiro Ato Institucional, de 09/04/1964: “É indispensável fixar o conceito do movimento civil e militar que acaba de abrir ao Brasil uma nova perspectiva sobre o seu futuro. $\mathrm{O}$ que houve $\mathrm{e}$ continuará a haver neste momento, não só no espírito e no comportamento das classes armadas, como na opiniâo pública nacional, é uma autêntica revolução".

12 Para a íntegra dos discursos de Auro Soares de Moura Andrade e Ribeiro da Costa durante a visita realizada em 16 de abril de 1964: Andrade (1985, p. 297 e ss.).

13 Declarado aposentado pelo decreto de 17/06/1964, nos termos do art. $7^{\circ}, \$ 1^{\circ}$, do Ato Institucional de 09/04/1964. Cf. BRASIL. Superior Tribunal de Justiça. Homenagem Póstuma. v. 22. Brasília: Secretaria de Documentação, 1997, p. 33.

14 Brasil. Diário Oficial da União. Seção 1 - 10.04.1964, p. 3.217.

15 Brasil. Comissão Nacional da Verdade. Relatório v. I, dez./2014, p. 935.

16 A respeito da ampliaçáo do entendimento do Supremo sobre a própria competência para examinar casos envolvendo a aplicação da lei n. 1.802/1953 (Lei de Segurança Nacional), o recurso no HC n. 40.865 , julgado em 05/08/1964 e o HC n. 41.879, julgado em 17/03/1965, ambos concedendo a liberdade a civis investigados pela prática de crimes sujeitos, a princípio, à jurisdição militar nos termos do AI-2.

17 Decisões nos HCs n. 41.609/CE (Percival Barroso); 41.891/AC (José Augusto de Araújo); 41.049/AM (Plínio Ramos Coelho); 41.296/GO (Mauro Borges), e 42.108/PE (Miguel Arraes), os três últimos analisados em Vale (1976, pp. 57-92). A decisão no caso Arraes deu, também, origem a um conflito entre o presidente do STF, Ribeiro da Costa, e o chefe do Estado-maior do I Exército, general Edson de Figueiredo, que se recusara inicialmente a cumprir a ordem, considerando-a "um abuso". A situação foi contornada após a interferência de Castello Branco, quando Arraes foi liberado e exilou-se na Argélia. Ver Gaspari (2002, p. 257).

18 HCs n. 46.405/GB (professor Darcy Ribeiro); 43.829/ GB (professor Mário Schenberg); 45.060/GB (arquiteto Vilanova Artigas); 40.976/GB (jornalista Carlos Heitor Cony), e 42.560/PE (ex-deputado Francisco Julião Arruda de Paula, líder das Ligas Camponesas e preso há um ano e meio sem condenação). Relatado pelo min. Luiz Gallotti que negava a ordem, este último caso, julgado em 27.9.1965, marcou uma divisão da Corte. Ver Valério (2010, p. 101).

19 Como ficou evidenciado no editorial datado de 14.4.1964, intitulado "Expurgo no âmbito do Judiciário". 
20 Brasil. Conselho de Segurança Nacional. 45a sessão do Conselho de Segurança Nacional. 16/01/1969. Sessão que precedeu a publicação do decreto de aposentadoria dos ministros.

21 As seis cartas foram doadas por Maria de Lourdes Kelly ao Arquivo Nacional (Fonte: BR RJANRIO TI), em 1993.

22 Apesar de ter se colocado na Liga de Defesa da Legalidade e manifestado a favor da posse de João Goulart em 1961, Sobral Pinto apoiou sem restriçôes a ascensão dos militares em 1 de abril de 1964, tendo escrevido cartas aos comandantes do 1o e 4o Exércitos antes do golpe, considerando que a "bolchevização do Brasil havia começado". Ver Goldman e Muaze (2010, p. 25). Contudo, já em 9 de abril de 1964, o advogado enviou carta a Castello Branco criticando o primeiro ato institucional (Pinto, 1977, p. 65) e apresentou-se como advogado de diversos perseguidos e presos políticos que tiveram seus mandatos cassados. Para as correspondências de Sobral Pinto dirigidas a diversas autoridades, incluindo Castello Branco, Costa e Silva, Geisel e Médici em defesa da advocacia, dos direitos de presos políticos, além das denúncias de tortura e violaçôes aos direitos humanos no país, ver Pinto (1977).

23 Publicada no Correio da Manhã, em 20/10/1965. Nela o presidente do STF condenava a intervenção do Executivo no Legislativo e Judiciário, criticando abertamente o projeto de reforma que tramitava na Câmara para aumentar o número de ministros. Oportunidade em que, só então, denunciou os militares por "fazer ruir o sistema constitucional [...] coisa jamais vista em países civilizados, pois nos regimes democráticos não são os militares os mentores da Nação". No que foi apoiado pelo deputado Paulo Coelho em longo discurso na Câmara. Ver Vale (1976, pp. 102-118).

24 Costa e Silva apud Gaspari (2002, p. 271). Ver também Dulles (2007, p. 124) e o depoimento de Gustavo Moraes Rego, tenente-coronel assessor de Geisel, que presenciou o episódio. Ver Rego (1994, pp. 37-72).

25 Tradicionalmente chamado de court packing, a medida interferiu diretamente na composição da cúpula da Suprema Corte com o objetivo de ajustá-la à diretriz política governamental. Tal qual ocorreu no plano de reorganização da Suprema Corte norte-americana por Roosevelt, após decisóes contrárias ao New Deal em 1937, ver Kline (1999, pp. 863-954); além do caso da transição para a democracia na Argentina em 1990, quando Carlos Menem aumentou o número de ministros da Suprema Corte de cinco para nove integrantes, promovendo ele próprio as novas nomeaçôes, com aprovaçáo do Senado, como apontam Garoupa e Maldonado (2011, p. 619).

26 Chacon (1987, p. 201). Há registro de que Sobral também enviou carta a Carlos Medeiros Silva manifestando a sua reprovação à assunção do cargo. Ver Dulles (2007, p. 131).

27 Até mesmo enviando telegramas ao general Costa e Silva sobre o conflito com Ribeiro da Costa e, em seguida, ao ministro da Justiça, Juracy Magalhães e ao deputado Adauto Lúcio Cardoso (que logo se tornaria ministro do STF), afirmando que o ato era uma "ameaça aos inimigos do autoritarismo". Após a tentativa frustrada de fazer com que o Instituto dos Advogados Brasileiros denunciasse a inconstitucionalidade do AI-2 e a violação à independência judicial, Sobral Pinto renunciou a presidência do Instituto. Ver Dulles (2007, p. 127 e ss.) e Goldman e Muaze (2010, p. 32).

28 Carta de Prado Kelly a Sobral Pinto, 04/11/1965. Arquivo Nacional (Fonte: BR RJANRIO TI).

29 Para uma análise sobre o impacto da EC n. 16/1965 para o funcionamento da jurisdição constitucional, ver Carvalho (2012, pp. 124-131) e Costa, Carvalho e Farias (2016, pp. 160-170).

$30 \mathrm{O}$ parecer do constituinte Adauto Cardoso destacou a necessidade de equiparaçáo dos vencimentos dos desembargadores com os dos secretários estaduais, a limitaçáo da incidência de impostos sobre a remuneraçáo dos juízes, além do grande volume de processos no STF.

31 Tal diagnóstico pareceu claro na dissertação defendida por Anhaia Mello em concurso para a cátedra de Direito Constitucional da USP em 1968, que apontou o abandono do modelo difuso articulado por Rui Barbosa para "entrarmos, decididamente, no campo da ação direta", a ponto de justificar e defender a criação de uma Corte Constitucional para o país. Ver Mello (1968, p. 199 e 209 e ss.).

32 STF. MS n. 19.873/SP, rel. min. Themístocles Cavalcanti, DJ 20/06/1968.

33 "Art. 20. - O provimento inicial dos cargos da Justiça Federal far-se-á pelo Presidente da República dentre brasileiros de saber jurídico e reputação ilibada".

34 Estabelecia a lei n. 5.010/1966: "Art. 19. Os Juízes Federais seráo nomeados pelo Presidente da República, dentre os nomes indicados, em lista quíntupla, pelo Supremo Tribunal Federal. $₫ 1^{\circ}$ O Supremo Tribunal Federal, para a organização da lista escolherá: a) três dentre nove nomes de Juízes Federais Substitutos propostos pelo Tribunal Federal de Recursos; b) dois nomes de bacharéis em Direito, com mais de trinta e 
menos de sessenta anos de idade, de notório merecimento e reputaçáo ilibada, e oito (8) anos, no mínimo de efetivo exercício na advocacia, no Ministério Público, na magistratura ou no magistério superior".

35 Nesse sentido, foram as conclusôes da Comissão Nacional da Verdade que registrou o modo particular de atuação de magistrados e ministros do STF na legitimação do regime: "sublinha-se que, em conjunto, as decisões do Poder Judiciário, quando do período ditatorial, refletem, muitas vezes, seu tempo e seus senhores; são expressóes da ditadura e de seu contexto de repressão e violência. Os magistrados que ali estiveram - ou melhor, que ali permaneceram - frequentemente eram parte dessa conjuntura, até mesmo porque, por meio da ditadura militar, foi-lhes garantido um assento naqueles tribunais. Quem quer que tenha sido nomeado para o STF, por exemplo, durante a ditadura, tinha clareza das circunstâncias a que estavam jungidos e quais votos eram esperados da sua lavra; sabiam da ausência de garantias dos magistrados; conheciam as reformas promovidas na composição e atribuições do tribunal; e, sobretudo, eram cônscios acerca de quem deveriam servir".

36 STF. Representação n. 749, rel. min. Adalício Nogueira, julgado em 04/12/1968. Íntegra do debate em: STF (1976). Representaçóes por Inconstitucionalidade. Tomo II (Pará a Sergipe), pp. 207-332.

37 STF. Representação n. 746/GB, rel. min. Gonçalves de Oliveira, julgado em 07/03/1968. O recurso ao argumento da simetria havia sido utilizado pelo STF para declarar inconstitucionais dispositivos da Constituição da Guanabara no julgamento da Representação no 751, em 19/10/1967, que concedia ao Conselho de Magistratura estadual competência para fiscalização financeira, poder disciplinar e alterava as regras de nomeação do quinto constitucional para o Tribunal de Justiça.

38 Ver também MS n. 18.672/DF, ajuizado por José Carlos da Silva Arouca, e MS n. 19.003, ajuizado por Carlos Renan Kurtz, que também discutiram a validade da lista tríplice como critério de nomeação.

39 Arquivo Nacional. Ata da 49a sessão de 01/07/1969 do Conselho de Segurança Nacional, p. 151. Ver também: "Novas puniçôes atingem 81 pessoas", Jornal do Brasil, 02/07/1969, p. 3.

40 Brasil. Escola Superior de Guerra, 1969, p. 18.

41 E completou: "Dou o meu testemunho, não por vanglória ou ostentação de poderio, que é pecado, mas para gáudio da verdade e da democracia, por cujos ideais lutaremos sempre, que nunca sofremos aqui nenhuma pressão, nos nossos julgamentos". Ver Gonçalves de Oliveira (1968, p. 68).

42 Sobre as competências do STF, o ato excluiu a apreciação de habeas corpus nos casos relativos a segurança nacional, crimes políticos, ordem econômica e economia popular.

43 Atos que escancararam a crise no STF e mostraram a ausência de garantias da continuidade do funcionamento da Corte. Logo após as aposentadorias, na sessão de 05/02/1969, o ministro Luiz Gallotti prestou homenagem aos colegas. $\mathrm{O}$ discurso e as cartas com os pedidos de aposentadoria de Gonçalves de Oliveira e Lafayette de Andrada foram reproduzidos em Pires (1979, pp. 71-77). Após o episódio, Aliomar Baleeiro e Oswaldo Trigueiro assumiram a presidência e a vice-presidência da Corte, respectivamente.

44 Nesse sentido, a declaração para a imprensa do ministro Thompson Flores ao comentar a extinção do AI-5 pela EC n. 11, de 13/11/1978: "Acompanhei desde 1964, como magistrado de segunda instância, a perda dos predicamentos da magistratura, em decorrência da Revolução e das injunçóes criadas a partir delas. Os magistrados brasileiros, principalmente os do Rio Grande do Sul, que eu bem conheci, não se perderam na sua independência no desempenho de suas atribuiçóes inerentes ao exercício da função judicante [...]. Nunca soube, durante todo esse tempo, que um só juiz houvesse deixado de ser um homem de bem, deixasse de ser honrado, cedesse à subversão, ou comprometesse por outro modo a majestade da toga, pelo fato de estarem suspensas as prerrogativas constitucionais da magistratura. A independência de um magistrado, em verdade, está na força do seu caráter, da sua formaçâo moral, da sua probidade". Cf. Pires (1979, p. 66).

45 Baleeiro (1968, p. 104). A neutralidade de que falava Baleeiro foi descrita também por Lins e Silva, porém apenas no sentido político-partidário, pois para ele a neutralidade náo impediria "o ministro de pronunciar votos políticos. Por quê? Porque o Tribunal é um poder político da nação. Todos os votos são políticos". Ver Lins e Silva (1997, p. 387).

$46 \mathrm{O}$ número de processos julgados/arquivados por ano havia se reduzido de 11.929 para 6.282. "Um fato é certo: a Revolução, que não pode ser sentenciada por paixóes, interesses e ressentimentos do presente, quis manter o Supremo no papel político que inspirou a sua criação pelos fundadores da República. Ao invés de enfraquecê-lo, no meu entender, deu-lhe poderes políticos ainda mais graves e com maiores responsabilidades, como a competência para declarar, em tese, a inconstitucionalidade de leis federais e não, apenas, 
como antes, a das estaduais contrárias ao art. $7^{\circ}$, VII, da Carta de 1946". Ver Baleeiro (1968, p. 134).

47 STF. Reforma do Judiciário: diagnóstico. Ofício $n$. 142, de 17/06/1975, pp. 17-38.

48 Trecho extraído da edição n. 447 da revista Veja a partir do levantamento feito por Tatiana Senne Chicarino: A transição e a revista Veja: um estudo sobre política e democracia no Brasil. Disponível em: <http://www. pucsp.br/neamp/acervo/transicao_revista_veja/index. $\mathrm{html}>$. O habeas corpus e as garantias dos juízes foram reinseridas apenas com a EC n. 11 em outubro de 1978, que revogou o AI-5.

49 Lei n. 6.339/1976, que restringiu o debate político na cadeia de rádio de TV ao prever no inciso I do $\$ 1^{\circ}$ do art. 250 do Código Eleitoral que "na propaganda, os partidos limitar-se-ão a mencionar a legenda, o currículo e o número do registro dos candidatos na Justiça Eleitoral, bem como a divulgar, pela televisão, suas fotografias, podendo, ainda, anunciar o horário local dos comícios".

50 Sobral Pinto destacou que suas críticas se dirigiam aos militares que editaram a EC 7/1977 e não ao Supremo, cuja autonomia sofria novo ataque. Ver Dulles (2007, p. 188).

51 José Lira apud Koerner (2010, p. 308). No mesmo evento, em sentido contrário foi a fala de Miguel Seabra Fagundes, que destacou a função política do STF com ênfase nos primeiros 30 anos da República e o papel da Corte contra os abusos do governo. Ver Fagundes (1978, pp. 1-10).

52 "A maior conquista do regime, entre nós, foi a transformação de uma Corte de Julgamentos Judiciários num instrumento admirável de Poder Político". José Lira apud Koerner (2010, p. 309).

53 Texto integral do discurso e pronunciamento de Ernesto Geisel disponível em: <http://goo.gl/XSu5Lv>.

54 Pécaut (1990, p. 202), que registra o grande aumento do consumo de bens culturais, como livros, peças teatrais, discos e cinema, no período.

55 Sobre as disputas em torno da independência judicial e a participação do STF no processo constituinte ver Carvalho (2017, pp. 31-77) e Koerner e Freitas (2013, pp. 141-184).

\section{BIBLIOGRAFIA}

ANDRADE, A. M. (1985), Um Congresso contra o arbitrio: diários e memórias. Edição póstuma revista por Glauco Carneiro. Rio de Janeiro, Nova Fronteira.
BALEEIRO, A. (1968), O Supremo Tribunal Federal, esse outro desconhecido. Rio de Janeiro, Forense.

(1972), "A função política do judiciário". Revista Forense, 68 (238): 5-14.

BARBOSA, L. (2012), História Constitucional Brasileira: mudança constitucional, autoritarismo e democracia no Brasil pós-1964, Brasília, Ediçóes Câmara.

BARROS, R. (2008), "Courts out of context: authoritarian sources of judicial failure in Chile (19731990) and Argentina (1976-1983)", in T. Ginsburg e T. Moustafa (eds.), Rule by law. The politics of Courts in authoritarian regimes, Nova York, Cambridge University Press, pp. 156-179.

BOHOSLAVSKY, J. P. (2015), "Introducción: entre cumplicidad militante, complacencia banal y valiente independencia", in J. P. Bohoslavsky (ed.) ¿Usted también, doctor? Complicidad de jueces, fiscales y abogados durante la dictadura, Buenos Aires, Siglo Veintiuno, pp. 21-41.

CARVALHO, A. (2012), Efeito vinculante e concentração da jurisdição constitucional no Brasil. Brasília, Consulex.

. (2016), Imagens da imparcialidade: entre o discurso constitucional e a prática judicial. Tese de doutorado em Direito. Brasília, UnB.

(2017), "Juscorporativismo: os juízes e o Judiciário na Assembleia Nacional Constituinte". Revista Brasileira de Estudos Politicos, 114: 31-77.

CHACON, V. (1987), Vida e morte das constituiçóes brasileiras. Rio de Janeiro, Forense.

CODATO, A. (2005), "Uma história política da transiçáo brasileira: da ditadura militar à democracia". Revista de Sociologia e Política, 25: 83-106.

CORRÊA, O. D. (1994), "A ordem jurídica e a Revoluçáo de 1964”, in E. Raposo (org.), 1964 - 30 anos depois, Rio de Janeiro, Agir.

COSTA, A.; CARVALHO, A. \& FARIAS, F. (2016), "Controle de constitucionalidade no Brasil: eficácia das políticas de concentração e seletividade". Direito GV, 12 (1): 155-187.

DÍAZ-ASENSIO, J. A. M. (2012), “¿Porque los autócratas limitan judicialmente su poder? Un análisis comparado del establecimiento de altos tribunales en regímenes autoritarios". Revista de Estudios Políticos, Madri, 158: 41-74. 
DULLES, J. (2007), Resisting Brazil's Military Regime: an account of the battles of Sobral Pinto. Austin, University of Texas Press.

FAGUNDES, M. S. (1978), "A função política do Supremo Tribunal Federal”. Revista de Direito Administrativo, 134: 1-10.

GASPARI, E. (2002), A ditadura envergonhada. São Paulo, Companhia das Letras.

GAROUPA, N. \& MALDONADO, M. (2011), "The Judiciary in political transitions: the critical role of U.S. Constitutionalism in Latin America”. Cardozo Journal of International and Comparative Law, 19: 593-644.

GOLDMAN, E. \& MUAZE, M. (2010), "Sobral Pinto: uma memória em construção”, in F. Sá, O. Muntreal Filho e P. E. M. Martins (orgs.), Os advogados e a ditadura de 1964: a defesa dos perseguidos políticos no Brasil, São Paulo, PUC-Rio.

GONÇALVES DE OLIVEIRA, A. (1968), Discursos no Supremo Tribunal Federal. Brasília, Alvorada.

HILBINK, L. (2008), "Agents of anti-politics: Courts in Pinochet's Chile", in T. Ginsburg e T. Moustafa (eds.), Rule by law. The politics of Courts in authoritarian regimes, Nova York, Cambridge University Press, pp. 102-131.

KLINE, S. (1999), "Revisiting FDR's Court Packing Plan: are the current attacks on judicial independence so bad?". McGeorge Law Review, 30: 863-951.

KOERNER, A. (2010), "Uma análise política do processo de representaçáo de inconstitucionalidade pós-64". Revista da EMARF Cadernos Temáticos - Justiça constitucional no Brasil: politica e direito, pp. 299-328.

KOERNER, A. \& FREITAS, L. (2013), "O Supremo na Constituinte e a Constituinte no Supremo”. Lua Nova, 88: 141-184.

KOSELLECK, R. (2006), Futuro passado: contribuiçâa à semântica dos tempos históricos. Rio de Janeiro, Contraponto.

- (2012), Historia de conceptos: estudios sobre semántica y pragmática del lenguaje politico y social. Madri, Trotta.

LEAL, V. N. (1999), Problemas de Direito Público e outros problemas. Brasília, Imprensa Nacional.
LEMOS, R. (2004), "Poder Judiciário e poder militar (1964-1969)”, in C. Castro, V. Izecksohn e H. Kraay (orgs.), Nova história militar brasileira, Rio de Janeiro, Ed. FGV/Bom Texto, pp. 409-438.

LIMA, H. (1974), Travessia - Memórias. Rio de Janeiro, José Olympio.

LINS E SILVA, E. (1997), O salão dos passos perdidos: depoimento ao CPDOC. Rio de Janeiro, Nova Fronteira/Ed. FGV.

LINZ, J. (1973), "The future of an authoritarian situation or the institutionalization of an authoritarian regime: the Case of Brazil", in A. Stepan (org.), Authoritarian Brazil: origins, policies, and future, New Haven/Londres, Yale University Press, pp. 233-254. . (1979), "Regimes autoritários", in P. S. Pinheiro (coord.), O Estado autoritário e movimentos populares, Rio de Janeiro, Paz e Terra, pp. 121-215.

MELLO, J. L. A. (1968), Da separação de poderes à guarda da Constituição. São Paulo, Revista dos Tribunais.

MOUSTAFA, T. \& GINSBURG, T. (2008), "Introduction: the function of Courts in authoritarian politics", in T. Ginsburg e T. Moustafa (eds.), Rule by law. The politics of Courts in authoritarian regimes, Nova York, Cambridge University Press.

O'DONNELL, G. (1979), Modernization and bureaucratic-authoritarianism: studies in South American politics. Berkeley: Institute of International Studies, University of California.

OLIVEIRA, F. L. (2004), "O Supremo Tribunal Federal no processo de transição democrática: uma análise de conteúdo dos jornais Folha de S.Paulo e O Estado de S. Paulo". Revista de Sociologia e Politica, 22: 101-118.

. (2012), Supremo Tribunal Federal: do autoritarismo à democracia. Rio de Janeiro, Elsevier.

PAIXÂO, C. (2014), "Autonomia, democracia e poder constituinte: disputas conceituais na experiência constitucional brasileira (19642014)". Quaderni Fiorentini per la Storia del Pensiero Giuridico Moderno, 43 (I): 415-458.

PAIXÃO, C. \& BARBOSA, L. (2008), "Cidadania, democracia e Constituiçáo: o processo de convocação da Assembleia Nacional Constituinte 
de 1987-88”, in F. H. U. Pereira e M. T. F. Dias (orgs.), Cidadania e inclusão social: estudos em homenagem à professora Miracy Barbosa de Sousa Gustin, Belo Horizonte, Fórum, pp. 121-132.

PÉCAUT, D. (1990), Os intelectuais e a politica no Brasil: entre o povo e a nação. São Paulo, Ática.

PEREIRA, A. (2005), Political (in)justice: authoritarianism and the rule of law in Brazil, Chile and Argentina, Pittsburgh, University of Pittsburgh Press.

PINTO, S. (1977), Liçôes de liberdade. 2 ed. Belo Horizonte, UCMG.

PIRES, E. (1979), O julgamento da liberdade. Brasília, Senado Federal ( col. Machado de Assis).

QUEIROZ, R. M. R. (2015), "Cinquenta anos de um conflito: o embate entre o ministro Ribeiro da Costa e o general Costa e Silva sobre a reforma do STF (1965), Dossiê Direito e Memória”. Direito $G V, 11$ (1): 323-342.

REGO, G. M. (1994), "Depoimento", in M. C. D’Araujo, G. A. D. Soares e C. Castro (orgs.), Visóes do golpe: a memória militar sobre 1964, Rio de Janeiro, Relume Dumará.

SAJÓ, A. (2003), "Erosion and decline of the rule of law in Post-Communism: an introduction", in A. Sajó (ed.), Out of and into anthoritarian law, The Hague, Kluwer Law International, pp. ix-xxiii.

SEELAENDER, A. (2009), "Juristas e ditaduras: uma leitura brasileira”, in R. M. Fonseca e A. C. Seelaender, História do direito em perspectiva: do antigo regime à modernidade, Curitiba, Juruá, pp. 415-432.

TELLES JUNIOR, G. (1965), A democracia e o Brasil: uma doutrina para a revolução de março. São Paulo, Revista dos Tribunais. . (1977), "Carta ao Povo Brasileiro". Revista da Faculdade de Direito da Universidade de São Paulo, 72 (2): 411-425.

VALE, O. T. (1976), O Supremo Tribunal Federal e a instabilidade politico-institucional. Rio de Janeiro, Civilização Brasileira.

VALÉRIO, O. (2010), A toga e a farda: o Supremo Tribunal Federal e o regime militar (1964-1969). Dissertação de mestrado em Direito. São Paulo, USP. VIOTTI DA COSTA, E. (2006), Supremo Tribunal Federal e a construção da cidadania. São Paulo, Unesp.
Outras fontes

BRASIL. Arquivo Nacional (Fonte: BR RJANRIO TI).

BRASIL (1964). Diário Oficial da União. Seção 1 - 10.04.1964, p. 3.217.

BRASIL (1969). Escola Superior de Guerra. Aspectos de Guerra Contemporânea - A Guerra Revolucionária. Documento reservado. Arquivo Ana Lagôa.

BRASIL (1969). Conselho de Segurança Nacional. Ata da $45^{\mathrm{a}}$ sessão do Conselho de Segurança Nacional. 16 de janeiro de 1969.

BRASIL (1969). Conselho de Segurança Nacional. Ata da 49a sessão do Conselho de Segurança Nacional. 01 de julho de 1969.

BRASIL (1997). Superior Tribunal de Justiça. Ministro José de Aguiar Dias: Homenagem Póstuma. (Coletânea de julgados no TFR e STJ) v. 22. Brasília, Secretaria de Documentação.

BRASIL. (2014). Comissão Nacional da Verdade. Relatório. Volume I. Capítulo 17. O Judiciário na Ditadura. Brasília, CNV.

STF. HC n. 40.910/PE, rel. min. Hahnemann Guimarães, julgado em 24.08.1964.

STF. Representação n. 746/GB, rel. min. Gonçalves de Oliveira, julgado em 07.03.1968.

STF. MS n. 19.873/SP, rel. min. Themístocles Cavalcanti, julgado em 20.6.1968.

STF. MS n. 18.972/DF, rel. min. Aliomar Baleeiro, julgado em 11.09.1968.

STF. Representação n. 749, rel. min. Adalício Nogueira, julgado em 4.12.1968.

STF. Representação n. 907/MT, rel. min. Aliomar Baleeiro, julgado em 1.12.1973.

STF. Reforma do Judiciário: diagnóstico. Ofício n. 142, de 17 de junho de 1975.

STF e Senado Federal. Representações por Inconstitucionalidade. Tomo I (Alagoas a Minas Gerais). Brasília, 1976.

STF e Senado Federal. Representaçóes por Inconstitucionalidade. Tomo II (Pará a Sergipe). Brasília, 1976. 


\section{ENTRE O DEVER DA TOGA E O APOIO À FARDA: INDEPENDÊNCIA JUDICIAL E IMPARCIALIDADE NO STF DURANTE O REGIME MILITAR}

\author{
Alexandre Douglas Zaidan de Carvalho \\ Palavras-chave: Supremo Tribunal Fede- \\ ral; Independência Judicial; Poder Judici- \\ ário; Regime Militar.
}

As disputas discursivas sobre a autonomia do Poder Judiciário e seu envolvimento com as demais instituiçôes políticas marcam o sentido de independência judicial como condição da imparcialidade da jurisdição. No entanto, a observação da historicidade da participaçáo de juristas e juízes, em particular dos ministros do STF, na construção do próprio espaço político-institucional ainda ocupa uma reduzida dimensão nas análises de cientistas sociais sobre o acesso à justiça no Brasil. Ao procurar combinar a análise dos influxos do regime ditatorial sobre as funçóes do Supremo Tribunal Federal no texto constitucional e as manifestações dos ministros sobre seu próprio papel institucional durante a ditadura, este texto traça alguns aspectos históricos relevantes para a compreensáo da complexa articulaçáo entre política e direito, na qual foram desenhadas as disputas por autonomia da Suprema Corte no período da ditadura civil-militar no país.

\section{BETWEEN THE DUTY \\ OF THE ROBE AND THE \\ SUPPORT OF FATIGUES: JUDICIAL INDEPENDENCE AND IMPARTIALITY IN THE BRAZILIAN SUPREME COURT DURING THE MILITARY REGIME}

\author{
Alexandre Douglas Zaidan de Carvalho \\ Keywords: Brazilian Supreme Court; \\ Judicial Independence; Judicial Power; \\ Military Regime.
}

Argumentative disputes regarding the autonomy of the Judicial Power and its engagement with other political institutions mark the notion of judicial independence as a condition for judicial impartiality. It is also important to stress that a historical inquiry concerning the participation of legal experts and judges, in particular Brazilian Supreme Court magistrates, on the process of constructing their own political-institutional space, unfortunately, still occupies a mitigated importance in social scientist's findings when dealing with the access to justice in Brazil. This paper seeks to combine the analysis of the influxes from the dictatorship period, concerning the Supreme Court's functions under the Constitutional commands, and the magistrates' declarations about their own institutional role during the dictatorial regime. It also aims to bring some relevant historical aspects to a better understanding of the complex relationship between politics and law, in which disputes for the Supreme Court's autonomy were drawn in the period of civil-military dictatorship in Brazil.

\section{ENTRE LE DEVOIR DE LA TOGE ET LE SUPPORT À L'UNIFORME: INDÉPENDENCE JUDICIAIRE ET IMPARTIALITÉ DE LA COUR SUPRÊME BRÉSILIENNE PENDANT LE RÉGIME MILITAIRE}

Alexandre Douglas Zaidan de Carvalho

Mots-clés: Cour Suprême Brésilienne; Independence judiciaire; Pouvoir Judiciaire; Régime Militaire

Les disputes discursives au sujet de l'autonomie du pouvoir judiciaire et son implication auprès des autres institutions politiques marquent le sens de l'indépendance judiciaire en tant que condition de l'impartialité de la juridiction. Néanmoins, l'observation de l'historicité de la participation des juristes et de juges, en particulier les magistrats de la Cour Suprême Brésilienne, dans la construction de leur propre espace politico-institutionnel occupe encore une dimension réduite dans l'analyse des chercheurs en sciences sociales sur l'accès à la justice au Brésil. En essayant de combiner l'analyse des affluences de la dictature sur des fonctions de la Cour suprême dans le texte constitutionnel et les manifestations des magistrats sur leur propre rôle institutionnel pendant la dictature, cet article trace quelques aspects historiques marquants pour comprendre l'articulation complexe entre la politique et le droit, dans laquelle ont été tracées les disputes pour l'autonomie de la Cour dans la période de la dictature civile-militaire au Brésil. 